
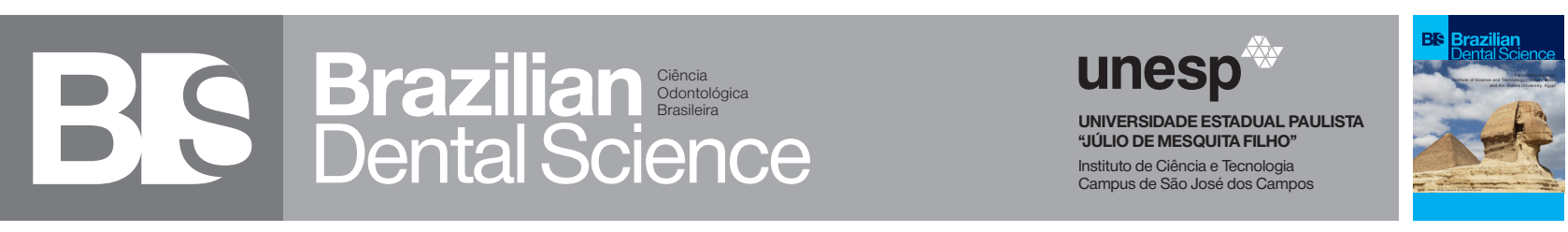

\title{
Effect of age-related alterations on the biomechanics of teeth affected by non-carious cervical lesions
}

\author{
Efeito de alterações relacionadas à idade na biomecânica de dentes afetados por lesões cervicais não-cariosas
}

\begin{abstract}
Marina Gullo AUGUSTO ${ }^{1}$, Tabata do Prado SATO ${ }^{2}$, Maria José Domingues de CASTRO ${ }^{1}$, Marcia Carneiro VALERA ${ }^{1}$, Alexandre Luis Souto BORGES ${ }^{2}$, Eduardo BRESCIANI ${ }^{1}$

1 - São Paulo State University (Unesp) - Institute of Science and Technology, São José dos Campos - Department of Restorative Dentistry - SP - Brazil.

2 - São Paulo State University (Unesp) - Institute of Science and Technology, São José dos Campos - Department of Dental Materials and Prosthodontics - SP - Brazil.
\end{abstract}

\begin{abstract}
Objective: The prevalence of non-carious cervical lesions (NCCLs) has increased in the recent years, especially in the elderly population. The successful prevention and treatment of those lesions requires an understanding of the biomechanics of aged teeth. Considering the importance of such aspect, the impact of the age-related dentin deposition on the stress distribution of NCCLs was evaluated by means of finite element analysis. Material and Methods: A 2-dimensional model of a sound maxillary first premolar was created using CAD software. Two tooth geometries (sound, aged) and two lesion shapes (wedge, saucer) were simulated to the model. The mesh was built with 35,000 triangle and square elements of $0.1 \mathrm{~mm}$ in length. All tissues were considered isotropic, homogeneous and linear. Occlusal surfaces were loaded with 300 $\mathrm{N}$ for simulating normal chewing forces. The stress distribution was analyzed by a color scale and by the maximum principal stress at the cavosurface line angle. Results: The aged models presented lower stress concentration in the overall system in comparison to sound models. The sharp angle of wedge shaped lesions promoted higher stress concentration at the center of cavosurface angle, favoring the lesions progression. Conclusion: Considering the limitations of the current methodology, it is possible to conclude that aged tooth is a more compact structure that can better respond to stress loadings. This protective intrinsic mechanism should be considered when adopting preventive and restorative measures for NCCLs for the elderly.
\end{abstract}

\section{KEYWORDS}

Aging; Finite element analysis; Non-carious; Cervical lesions.

\section{RESUMO}

Objetivo: A prevalência de lesões cervicais nãocariosas (NCCLs) tem aumentado nos últimos anos, especialmente em idosos. A prevenção e o tratamento bem-sucedidos dessas lesões requerem um entendimento da biomecânica dos dentes envelhecidos. Considerando a importância de tal aspecto, o impacto da deposição de dentina que ocorre com a idade na distribuição de estresse de NCCLs foi avaliado por meio da análise de elementos finitos. Material e Métodos: Um modelo bidimensional de um primeiro pré-molar superior foi criado usando o software CAD. Duas geometrias de dentes (padrão, envelhecido) e duas formas de lesão (cunha, pires) foram simuladas ao modelo. A malha foi construída com 35.000 elementos triangulares e quadrados de 0,1 mm de comprimento. Todos os tecidos foram considerados isotrópicos, homogêneos e lineares. Superfícies oclusais foram carregadas com $300 \mathrm{~N}$ para simular forças normais de mastigação. A distribuição das tensões foi analisada por uma escala de cores e pela tensão principal no ângulo da linha cavo-superficial. Resultados: Os modelos envelhecidos apresentaram menor concentração de tensão no sistema geral em comparação aos modelos padrão. O ângulo agudo das lesões em cunha promoveu maior concentração de tensão no centro do ângulo cavo-superficial, favorecendo a progressão das lesões. Conclusão: Considerando as limitações da metodologia atual, é possível concluir que o dente envelhecido é uma estrutura mais compacta que pode responder melhor às cargas de estresse. Este mecanismo intrínseco de proteção deve ser considerado ao adotar medidas preventivas e restaurativas para as NCCLs em idosos.

\section{PALAVRAS-CHAVE}

Envelhecimento; Análise de elementos finitos; Lesões cervicais não-cariosas. 


\section{INTRODUCTION}

$\mathrm{N}$ on-carious cervical lesions (NCCLs) are characterized as the loss of dental structure at the cervical area of the tooth in absence of caries [1]. The prevalence of these lesions has significantly increased throughout the world in the recent years [2]. However, there are evidences that elderly patients present more NCCLs than young patients and moreover the severity of the lesions increases with age $[3,4]$.

The etiology of these lesions continues to be discussed in the literature, but there are strong evidences that it is a multifactorial process involving three mechanisms: stress concentration, friction and biocorrosion $[5,6]$. In cases in which the most significant mechanism is stress concentration, the lesions usually present sharp angles, being known as wedge shaped. Whereas, in cases where biocorrosion is the most significant mechanism, the lesions usually present smooth angles and are known as saucer shaped [7].

Excessive occlusal forces lead to stress concentration in the cervical area, disrupting the chemical bonds between hydroxyapatite crystals and making them susceptible to chemical dissolution [8]. However, aged teeth are expected to respond better to excessive loads due the deposition of secondary dentin (produced after the root formation) and tertiary dentin (produced in response to damaging stimulus) $[9,10]$. This protective dentin deposition reduces the pulp cavity area making the tooth a more compact structure that may be more resistant to fracture.

Thus, in elderly patients the successful prevention and treatment of those lesions requires an understanding of the impact of dentin deposition in the stress distribution of NCCL. However, there is a lack of information in the literature regarding this question. Thus, aiming to address the reported scenario, this study evaluated the influence of the agerelated dentin deposition on stress distribution of NCCLs by means of finite element analysis.

\section{MATERIALS AND METHODS}

\section{Finite Element Modeling}

The image of a healthy maxillary first premolar in a buccolingual longitudinal plane was replicated in CAD (Computer Aided Design) software (Rhinoceros, version 4.0, McNeel North America, Seattle, WA, USA). The image was virtually inserted into the image of a previously modeled alveolus consisting of posterior maxillary alveolar process [11]. This model (sound) was used as reference for further models presenting variations on pulp area (young, aged) and on lesion shape (no lesion, saucer shape, wedge shape). All lesions had their areas standardized in $1.40 \mathrm{~mm} 2$. In order to provide a more realistic simulation it was assumed that the deposition of secondary dentin decreased the pulp area and the deposition of tertiary dentin (with lower elastic modulus than primary and secondary dentin) occurred in the area around the lesions, as shown in Figure 1.

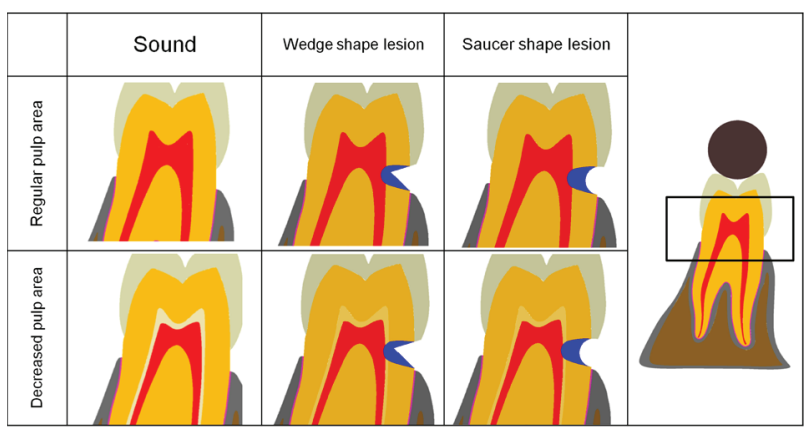

Figure 1 - Geometry of the different models. Green areas represent secondary dentin and blue areas represent tertiary dentin. 


\section{Loading conditions}

Considering that the average maximum biting force of a maxillary premolar is $291 \mathrm{~N}$ [12], the force applied during the simulations was set to $300 \mathrm{~N}$ (Figure 2).

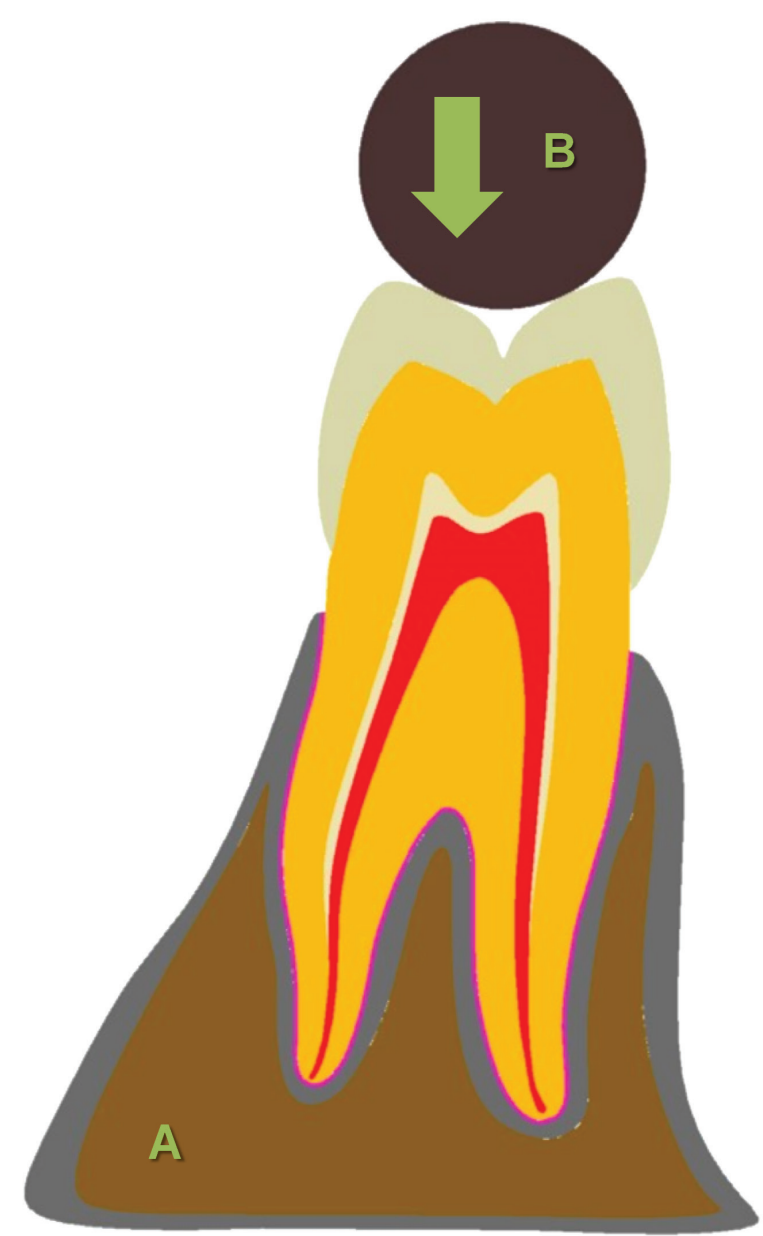

Figure 2 - The final model of the tooth inserted into the bone. A) Fixed support; B) Load location and direction.

\section{Finite Element Analysis}

These CAD models were imported as parasolid format files into ANSYS software (ANSYS 16.0, ANSYS Inc, Houston, TX, USA) for the numerical simulations by FEA. All tissues were considered homogenous, linearly elastic, and isotropic. Their mechanical properties are summarized in Table 1.
Table 1 - Mechanical properties of the materials used in the numerical simulations

\begin{tabular}{|cccc|}
\hline Material & $\begin{array}{c}\text { Elastic } \\
\text { Modulus(GPa) }\end{array}$ & $\begin{array}{c}\text { Poisson's } \\
\text { Ratio }\end{array}$ & Reference \\
\hline $\begin{array}{c}\text { Enamel } \\
\begin{array}{c}\text { Primary/Secon- } \\
\text { dary dentin }\end{array}\end{array}$ & 41 & 0.3 & Ko et al, 1992[13] \\
\hline $\begin{array}{c}\text { Tertiary dentin } \\
\text { Pulp chamber }\end{array}$ & 19.3 & 0.3 & $\begin{array}{c}\text { Senawongse et al, } \\
\text { 2006 [14] }\end{array}$ \\
\hline $\begin{array}{c}\text { Periodontal } \\
\text { ligament }\end{array}$ & 0.002 & 0.45 & Rubin et al, 1983 [15] \\
\hline $\begin{array}{c}\text { Cancellous bone } \\
\text { Cortical bone }\end{array}$ & 1.37 & 0.39 & Holmes et al, 1996 [16] \\
\hline
\end{tabular}

The mesh was built with triangular and quadrilateral elements with slow transition and high smoothing as mesh controls. Tests varying the size of elements were carried out until 10\% of convergence of the results was reached, which determined the ideal element size at $0.1 \mathrm{~mm}$. The total number of elements was about 35,000 and 38,000 nodes for all models.

The stress distribution was qualitatively evaluated by means of a color scale, in which cold colors represent low stress concentration and hot colors represent high stress concentration. A quantitative analysis of maximal principal stress (MPa) was done by calculating the stress at the cavosurface line angle of each lesion.

\section{RESULTS}

Stress distribution for each simulated condition is shown in Figure 3. The models are presented without the supporting bone for a better visualization of the stress distribution at the root area.

In general, the aged models presented lower stress concentration at the cavosurface line angle than young models. In no-lesion models, higher stress concentration was observed at loading points in enamel and at cervical dentin above the pulp chamber. In models containing 
the lesions, it was possible to observe that the lesions had no effect on the overall stress distribution of the system but affected local stress concentrations. In wedge shaped models, higher stress concentration was observed at the cavosurface angle than in saucer shaped models.

The quantitative analysis of maximal principal stress (MPS) shows that the stress distribution at the cavosurface line angle is different in wedge and saucer shape lesions
(Figure 4). In wedge shape lesions, the stress concentration increased from the margins to the lesions center, creating a graph with a peak shape. In saucer shape lesions, the stress concentration decreased from the margins to the center, creating a graph with a valley shape. Wedge shape lesions presented higher MPS (100 MPa young; $75 \mathrm{MPa}$ - aged) than saucer shaped lesions (60 MPa - young; $35 \mathrm{MPa}$ - aged).

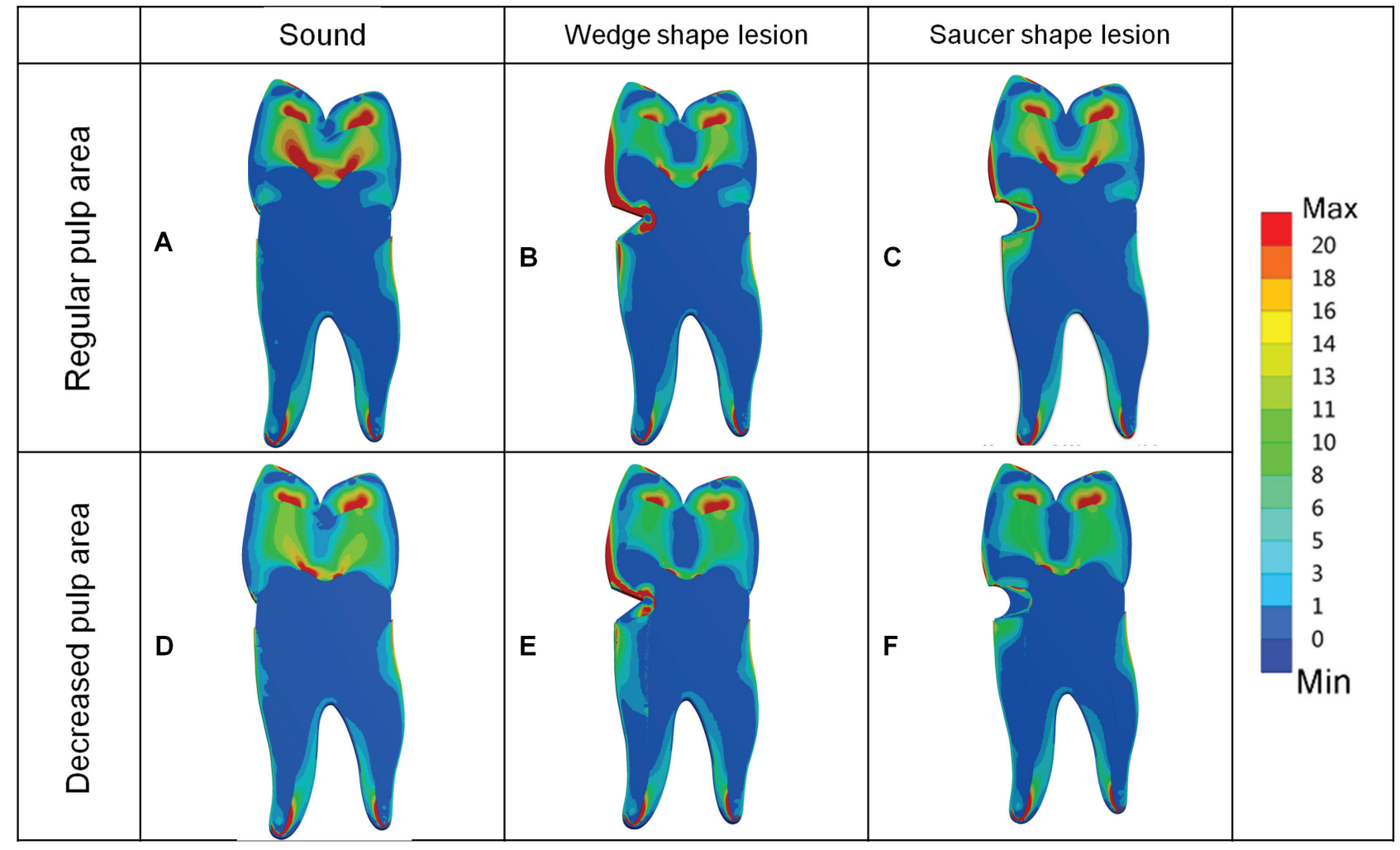

Figure 3 - Qualitative analysis of stress distribution in all subgroups. 

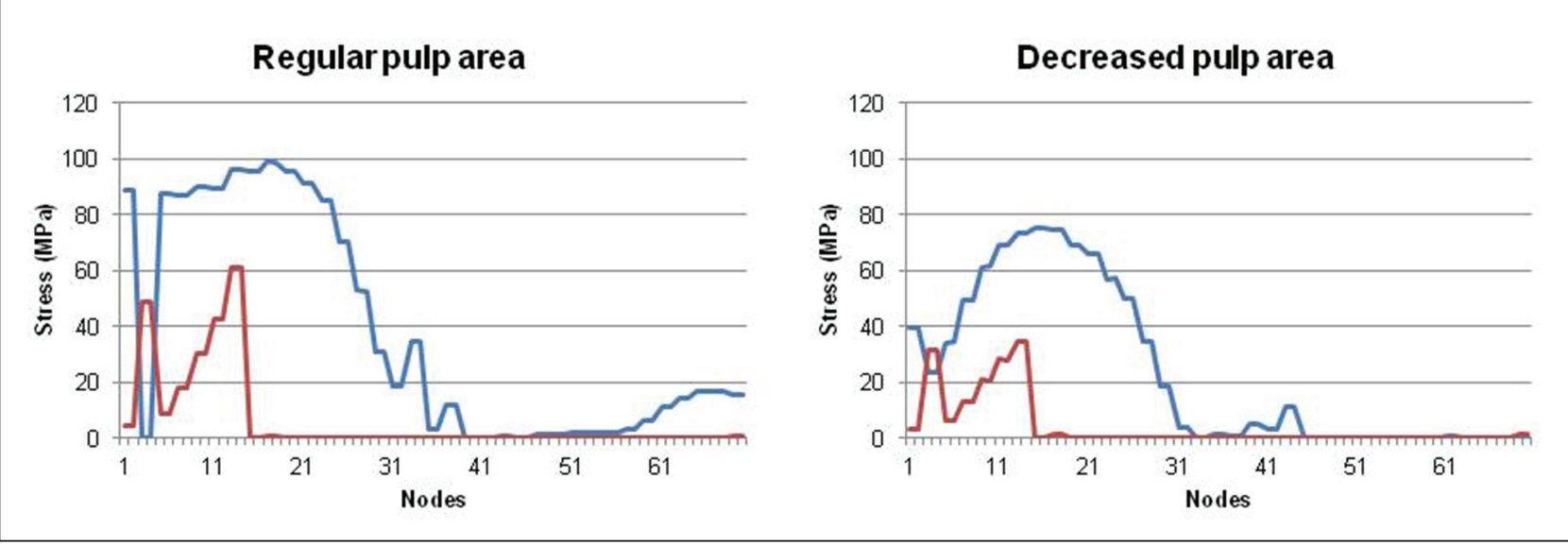

Figure 4 - Graphs representing the quantitative analysis of stress in the cavosurface angle of wedge shaped (blue) and saucer shaped (red) lesions.

\section{DISCUSSION}

The present study used two-dimensional FEA models that correspond to a simplification of the three-dimensional structures. The extrapolation of the obtained results to clinical scenarios should be carefully done since the computational simulation do not represent the in vivo conditions. However, this simplification highlights the importance of considering the biomechanical behavior of aged teeth before adopting preventive and therapeutic measures for elderly patients.

Resultant stresses within tooth are dependent upon the magnitude, direction, frequency, site of application, and duration of forces [17]. This study considered only normal chewing forces, in order to simplify the computational simulation. Other authors found differences in the stress distribution of NCCLs when applying different loads [18-20].

In no-lesion models, it is possible to observe that tensile stresses are mainly concentrated in dentin above the pulp chamber (Figure 3) because dentin presents lower elastic modulus than enamel, acting as a tension absorber [14]. Thus, since there is no hard tissue support in the area above the pulp chamber the stress tend to concentrate in this area [21].

Wedge shaped lesions presented higher stress concentration than sauce shaped lesions, what is in accordance to previous studies $[19,22]$. In wedge shaped lesions, the stress concentration increased from the margins to the lesions center. This happens because the sharp line angle in wedge shaped lesions favors stress concentration in the center, contributing to the lesions progression $[19,23]$.

The results of this study showed that aged tooth present lower stress concentration than young tooth at the cavosurface line angle of NCCL. The Figures 3 and 4 confirm that the dentin deposition promoted a decrease in the intensity of stress concentration, turning the tooth into a more compact structure that can better respond to stress loadings.

This mechanism might play a role in slowing down the progression of the NCCLs because the dentin deposition turns the tooth structure more resistant to the disruption of the chemical bonds between hydroxyapatite crystals. In addition, the sclerotic dentine found beneath cervical lesions presents tubules that are often occluded by a continuous growth of peritubular dentine, and this calcified tissue is more resistant to etching [24]. Thus, further studies should be conducted to evaluate if the elderly population present a higher prevalence of lesions associated to stress concentration (wedge shaped) or biocorrosion (sauce shaped). 
However, the current literature shows that the prevalence and severity of these lesions increase with aging [3]. This may be because the NCCLs are multifactorial condition and their cumulative effect on teeth during life may the main factor associated to the increased prevalence of these lesions in elderly population. Thus, the better response of teeth to stress concentration is not enough to successful prevent the emergence of theses lesions, reinforcing the necessity to control the multiple risk factors [6].

Stress concentration was found to be one of the causative factors for the failure of restorations placed in NCCL [25]. Aiming to increase the longevity these restorations, beveling the gingival margin was proposed to reduce the risk of fracture [26, 27], microleakage [28]. However, in cases of elderly patients the adoption of a non-conservative protocol like that should be carefully reconsidered since the dentin deposition associated to aging provides naturally a better stress distribution in the aged teeth.

\section{CONCLUSIONS}

Considering the limitations of the current methodology, it is possible to conclude that aged tooth is a more compact structure that can better respond to stress loadings. This protective intrinsic mechanism should be considered when adopting preventive and restorative measures for NCCLs. The sharp angle of wedge shaped lesions promoted higher stress concentration at the center of cavosurface angle, favoring the lesions progression.

\section{REFERENCES}

1. Aw TC, Lepe X, Johnson GH, Mancl L. Characteristics of noncarious cervical lesions: a clinical investigation. J Am Dent Assoc. 2002 Jun;133(6):725-33.

2. Salas MM, Nascimento GG, Vargas-Ferreira F, Tarquinio SB, Huysmans $\mathrm{MC}$, Demarco FF. Diet influenced tooth erosion prevalence in children and adolescents: Results of a meta-analysis and meta-regression. J Dent. 2015 Aug;43(8):865-75.

3. Borcic J, Anic I, Urek MM, Ferreri S. The prevalence of non-carious cervical lesions in permanent dentition. J Oral Rehabil. 2004 Feb;31(2):117-23.
4. Wood I, Jawad Z Paisley C, Brunton P. Non-carious cervical tooth surface loss: a literature review. J Dent. 2008 0ct;36(10):759-66.

5. Bartlett DW, Shah P. A critical review of non-carious cervical (wear) lesions and the role of abfraction, erosion, and abrasion. J Dent Res. 2006 Apr;85(4):306-12.

6. Grippo JO, Simring M, Coleman TA. Abfraction, abrasion, biocorrosion, and the enigma of noncarious cervical lesions: a 20 -year perspective. J Esthet Restor Dent. 2012 Feb;24(1):10-23.

7. Levitch LC, Bader JD, Shugars DA, Heymann HO. Non-carious cervical lesions. J Dent. 1994 Aug;22(4):195-207.

8. Lee WC, Eakle WS. Possible role of tensile stress in the etiology of cervical erosive lesions of teeth. J Prosthet Dent. 1984 Sep;52(3):37480.

9. Baume LJ. The biology of pulp and dentine. A historic, terminologictaxonomic, histologic-biochemical, embryonic and clinical survey. Monogr Oral Sci. 1980;8:1-220.

10. Walter C, Kress E, Gotz H, Taylor K, Willershausen I, Zampelis A. The anatomy of non-carious cervical lesions. Clin Oral Investig. 2014 Jan;18(1):139-46.

11. Borges AL, Borges AB, Xavier TA, Bottino MC, Platt JA. Impact of quantity of resin, $\mathrm{C}$-factor, and geometry on resin composite polymerization shrinkage stress in Class V restorations. Oper Dent. 2014 Mar-Apr;39(2):144-51.

12. Ferrario VF, Sforza C, Serrao G, Dellavia C, Tartaglia GM. Single tooth bite forces in healthy young adults. J Oral Rehabil. 2004 Jan;31(1):1822.

13. Ko CC, Chu CS, Chung KH, Lee MC. Effects of posts on dentin stress distribution in pulpless teeth. J Prosthet Dent. 1992 Sep;68(3):421-7.

14. Senawongse P, Otsuki M, Tagami J, Mjor I. Age-related changes in hardness and modulus of elasticity of dentine. Arch Oral Biol. 2006 Jun;51(6):457-63.

15. Rubin C, Krishnamurthy N, Capilouto E, Yi H. Clinical Science: Stress Analysis of the Human Tooth Using a Three-dimensional Finite Element Model. Journal of Dental Research. 1983 February 1, 1983:62(2):82-6

16. Holmes DC, Diaz-Arnold AM, Leary JM. Influence of post dimension on stress distribution in dentin. J Prosthet Dent. 1996 Feb;75(2):140-7.

17. Grippo JO, Masi JV. Role of biodental engineering factors (BEF) in the etiology of root caries. J Esthet Dent. 1991 Mar-Apr;3(2):71-6.

18. Benazzi S, Grosse IR, Gruppioni G, Weber GW, Kullmer 0. Comparison of occlusal loading conditions in a lower second premolar using threedimensional finite element analysis. Clin Oral Investig. 2014;18(2):369-75.

19. Guimaraes JC, Guimaraes Soella G, Brandao Durand L, Horn F, Narciso Baratieri L, Monteiro S Jr, Belli R. Stress amplifications in dental noncarious cervical lesions. J Biomech. 2014 Jan 22;47(2):410-6.

20. Lee $\mathrm{HE}$, Lin $\mathrm{CL}$, Wang $\mathrm{CH}$, Cheng $\mathrm{CH}$, Chang $\mathrm{CH}$. Stresses at the cervical lesion of maxillary premolar--a finite element investigation. J Dent. 2002 Sep-Nov;30(7-8):283-90.

21. Goel VK, Khera SC, Singh K. Clinical implications of the response of enamel and dentin to masticatory loads. J Prosthet Dent. 1990 0ct;64(4):446-54.

22. Kuroe T, Itoh H, Caputo AA, Konuma M. Biomechanics of cervical tooth structure lesions and their restoration. Quintessence Int. 2000 Apr;31(4):267-74. 
23. Eliguzeloglu E, Eraslan 0, Omurlu H, Eskitascioglu G, Belli S. The effect of cavity shape and hybrid layer on the stress distribution of cervical composite restorations. Eur J Dent. 2011 Apr;5(2):180-5.

24. Marshall GW, Jr., Chang YJ, Saeki K, Gansky SA, Marshall SJ. Citric acid etching of cervical sclerotic dentin lesions: an AFM study. Journal of biomedical materials research. 2000 Mar 5;49(3):338-44.

25. Oginni AO, Adeleke AA. Comparison of pattern of failure of resin composite restorations in non-carious cervical lesions with and without occlusal wear facets. J Dent. 2014 Jul;42(7):824-30.
26. Oilo G, Jorgensen KD. Effect of bevelling on the occurrence of fractures in the enamel surrounding composite resin fillings. J Oral Rehabil. 1977 0ct:4(4):305-9.

27. Coelho-de-Souza FH, Rocha Ada C, Rubini A, Klein-Junior CA, Demarco FF. Influence of adhesive system and bevel preparation on fracture strength of teeth restored with composite resin. Braz Dent J. 2010;21(4):327-31.

28. Retief $\mathrm{DH}$, Woods $\mathrm{E}$, Jamison HC. Effect of cavosurface treatment on marginal leakage in class $\mathrm{V}$ composite resin restorations. J Prosthet Dent. 1982 May;47(5):496-501.

\section{Marina Gullo Augusto}

(Corresponding address)

Universidade Estadual Paulista (Unesp)

Departamento de Odonotlgia Restauradora

Av. Eng. Francisco José Longo 777

Jardim São Dimas, São José dos Campos,

São Paulo, Brazil. CEP 12245-000

Date submitted: 2018 Aug 29

E-mail: marina.augusto@ict.unesp.br 